\title{
INTERAKSI PBL-MURDER, MINAT PENJURUSAN, DAN KEMAMPUAN DASAR MATEMATIS TERHADAP PENCAPAIAN KEMAMPUAN BERPIKIR DAN DISPOSISI KRITIS
}

\section{Maulana}

PGSD Universitas Pendidikan Indonesia Kampus Sumedang

Jalan Mayor Abdurrahman No. 211 Sumedang 45322

Email: maulana@upi.edu

\begin{tabular}{|c|c|}
\hline ABSTRACT & ABSTRAK \\
\hline $\begin{array}{l}\text { Selection of appropriate learning approaches } \\
\text { and strategies will facilitate the achievement of } \\
\text { these learning activities. Similarly, in mathematics } \\
\text { learning activities in PGSD (department of } \\
\text { preservice elementary school teacher), which is } \\
\text { demanding the development of a high level of } \\
\text { mathematical ability as well as critical thinking } \\
\text { skills. However, not many people are trying to } \\
\text { look for other factors in addition to the } \\
\text { approach/learning strategy, which is possible to } \\
\text { contribute to the development of critical thinking } \\
\text { abilities, such as students' major interest factor } \\
\text { (IPA [science] and non-IPA [non-science]) as well } \\
\text { as mathematical prior knowledge which has } \\
\text { been owned previously. In addition, affective } \\
\text { aspects that accompany any critical thinking } \\
\text { abilities (called critical thinking disposition) is a } \\
\text { study that is still rare. This paper briefly present to } \\
\text { peel the election factor of approaches and } \\
\text { learning strategies, ie., problem-based learning } \\
\text { with "MURDER" strategy, shared interests and their } \\
\text { interaction majors and mathematical prior } \\
\text { knowledge of the result of performance of } \\
\text { critical thinking skills and dispositions of PGSD } \\
\text { students. } \\
\text { Keywords: problem-based learning, the } \\
\text { "MURDER" strategy, the interest of majors, } \\
\text { mathematical prior knowledge, critical thinking } \\
\text { skills, critical thinking disposition. }\end{array}$ & $\begin{array}{l}\text { Pemilihan pendekatan dan strategi yang tepat, } \\
\text { tentu akan memudahkan tercapainya tujuan } \\
\text { kegiatan pembelajaran tersebut. Begitu pula } \\
\text { dalam kegiatan pembelajaran matematika di } \\
\text { PGSD, yang memang menuntut pengembangan } \\
\text { kemampuan matematis tingkat tinggi seperti } \\
\text { halnya kemampuan berpikir kritis. Akan tetapi, } \\
\text { tidak banyak orang yang mencoba melihat } \\
\text { adanya faktor lain di samping } \\
\text { pendekatan/strategi pembelajaran, yang } \\
\text { dimungkinkan ikut berkontribusi dalam } \\
\text { pengembangan kemampuan berpikir kritis } \\
\text { tersebut, misalnya saja faktor minat penjurusan } \\
\text { mahasiswa (IPA dan Non-IPA) serta kemampuan } \\
\text { dasar matematis yang telah dimiliki sebelumnya. } \\
\text { Selain itu, aspek afektif yang mengiringi } \\
\text { kemampuan berpikir kritis pun (disposisi kritis) } \\
\text { merupakan kajian yang masih jarang ditemui. } \\
\text { Tulisan ini hadir untuk mengupas secara singkat } \\
\text { mengenai faktor pemilihan jenis pendekatan } \\
\text { dan strategi pembelajaran, yakni problem-based } \\
\text { learning berstrategi "MURDER" dan interaksinya } \\
\text { bersama minat penjurusan serta kemampuan } \\
\text { dasar matematis terhadap hasil capaian } \\
\text { kemampuan berpikir dan disposisi kritis } \\
\text { matematis mahasiswa PGSD. } \\
\text { Kata kunci: problem-based learning, strategi } \\
\text { "MURDER", minat penjurusan, kemampuan dasar } \\
\text { matematis, kemampuan berpikir kritis matematis, } \\
\text { disposisi berpikir kritis matematis. }\end{array}$ \\
\hline
\end{tabular}

How to Cite: Maulana, M. (2015). INTERAKSI PBL-MURDER, MINAT PENJURUSAN, DAN KEMAMPUAN DASAR MATEMATIS TERHADAP PENCAPAIAN KEMAMPUAN BERPIKIR DAN DISPOSISI KRITIS. Mimbar Sekolah Dasar, 2(1), 1-20. doi:http://dx.doi.org/10.17509/mimbar-sd.v2i1.1318.

PENDAHULUAN ISU aktual dalam

pembelajaran matematika saat ini adalah

bagaimana upaya mengembangkan kemampuan berpikir tingkat tinggi (high order thinking skills-HOTS), serta menjadikannya sebagai tujuan penting yang harus dicapai dalam pembelajaran matematika. Kemampuan berpikir matematis tingkat tinggi bersifat nonalgoritmik, kompleks, melibatkan 
Maulana, Interaksi PBL-MURDER, Minat Penjurusan, dan Kemampuan Dasar Matematis...

kemandirian dalam berpikir, seringkali melibatkan suatu ketidakpastian sehingga membutuhkan pertimbangan dan interpretasi, melibatkan kriteria yang beragam dan terkadang memicu timbulnya konflik, menghasilkan solusi yang terbuka, juga membutuhkan upaya yang sungguh-sungguh dalam melakukannya (Resnick, 1987; Arends, 2004).

Sehubungan dengan kegiatan berpikir matematis tingkat tinggi, Schoenfeld (1992) membaginya menjadi beberapa hal yang meliputi: mencari dan mengeksplorasi pola, memahami struktur dan hubungan-hubungan matematis, menggunakan data, merumuskan dan memecahkan masalah, bernalar analogis, melakukan estimasi, menyusun alasan yang rasional, menggeneralisasi, mengomunikasikan ide-ide matematis, serta bagaimana memeriksa kebenaran suatu jawaban.

Salah satu kemampuan berpikir yang termasuk ke dalam kemampuan berpikir tingkat tinggi adalah kemampuan berpikir kritis. Ada empat desakan mengenai perlunya dibiasakan mengembangkan kemampuan berpikir kritis, yakni: (1) tuntutan zaman yang menghendaki warga negara dapat mencari, memilih, dan menggunakan informasi untuk kehidupan bermasyarakat dan bernegara, (2) setiap warga negara senantiasa berhadapan dengan berbagai masalah dan pilihan sehingga dituntut mampu berpikir kritis dan kreatif, (3) kemampuan memandang sesuatu dengan cara yang berbeda dalam memecahkan masalah, dan (4) berpikir kritis merupakan aspek dalam memecahkan permasalahan secara kreatif agar peserta didik dapat bersaing secara adil dan mampu bekerja sama dengan bangsa lain (Wahab, 1996; Maulana, 2007).

Berpikir kritis merupakan suatu proses yang berujung pada pembuatan kesimpulan atau keputusan yang logis tentang apa yang harus diyakini dan tindakan apa yang harus dilakukan. Berpikir kritis bukan hanya untuk mencari jawaban saja, melainkan lebih penting untuk menanyakan kebenaran jawaban, fakta, atau informasi yang ada, sehingga bisa ditemukan alternatif solusi yang terbaik (Ennis, 2000). Kemampuan berpikir kritis tentunya dapat dikembangkan melalui pembelajaran matematika di sekolah ataupun perguruan tinggi, yang menitikberatkan pada sistem, struktur, konsep, prinsip, serta kaitan yang ketat antara suatu unsur dan unsur lainnya. Matematika dengan hakikatnya sebagai ilmu yang terstruktur dan sistematis, sebagai suatu kegiatan manusia melalui proses yang aktif, dinamis, dan generatif, serta sebagai ilmu yang mengembangkan sikap berpikir kritis, objektif, dan terbuka, menjadi sangat penting dikuasai oleh peserta didik dalam menghadapi laju perubahan ilmu pengetahuan dan teknologi yang begitu pesat. 
Kenyataannya, seperti yang diungkapkan oleh Maier (1985) dan Begle (dalam Darhim, 2004), tidak dapat dimungkiri bahwa anggapan yang saat ini berkembang pada sebagian peserta didik adalah matematika merupakan bidang studi yang sulit dan tidak disenangi, hanya sedikit yang mampu menyelami dan memahami matematika sebagai ilmu yang dapat melatih kemampuan berpikir kritis. Padahal, mereka sendiri tahu bahwa matematika itu penting bagi kehidupannya. Selain anggapan buruk peserta didik terhadap matematika, Slettenhaar (2000) berpendapat pula bahwa pada model pembelajaran sekarang ini, secara umum aktivitas peserta didik hanya mendengar dan menonton pengajarnya melakukan kegiatan matematis, lalu pengajar itu menyelesaikan masalah dengan satu solusi, diakhiri pemberian soal latihan untuk diselesaikan sendiri oleh peserta didik. Kegiatan pembelajaran seperti itu, menurut Rif'at (2001) disebut sebagai rote learning, yakni kegiatan belajar yang hanya membuat peserta didik cenderung menghafal dan tanpa memahami atau tanpa mengerti apa yang diajarkan, sementara si pengajar sering tidak menyadarinya. Hal senada juga diungkapkan oleh Abdi (2004), bahwa sebagian peserta didik merasakan kesulitan dalam menyerap dan memahami pelajaran matematika, tetapi sulitnya memahami pelajaran matematika yang diajarkan itu diperkirakan berkaitan dengan cara mengajar guru di kelas yang tidak membuat peserta didik merasa senang dan simpatik terhadap matematika, pendekatan yang dilakukan guru matematika pada umumnya kurang bervariasi.

Jenning \& Dunne (1998) mengatakan bahwa kebanyakan peserta didik mengalami kesulitan dalam mengaplikasikan matematika dalam kehidupan sehari-harinya, karena pada pembelajaran matematika, dunia nyata hanya dijadikan tempat mengaplikasikan konsep. Hal lain yang menyebabkan sulitnya matematika bagi peserta didik adalah karena pembelajaran matematika dirasakan kurang bermakna. Guru dalam pembelajarannya di kelas tidak mengaitkan dengan pengetahuan sebelumnya (prior-knowledge) yang telah dimiliki oleh peserta didik dan mereka kurang diberikan kesempatan untuk menemukan kembali (reinvention) dan mengkonstruksi sendiri ide-ide matematika. Wahyudin (1999) mengatakan bahwa salah satu penyebab peserta didik lemah dalam matematika adalah kurang memiliki kemampuan untuk memahami (pemahaman), untuk mengenali konsepkonsep dasar matematika yang berkaitan dengan pokok bahasan yang sedang dibicarakan.

Bersandar pada alasan yang dikemukakan di atas, jelaslah bahwa kemampuan berpikir kritis peserta didik sangat penting untuk dikembangkan. Oleh karena itu, guru atau dosen 
Maulana, Interaksi PBL-MURDER, Minat Penjurusan, dan Kemampuan Dasar Matematis...

hendaknya mengkaji dan memperbaiki kembali praktik-praktik pengajaran yang selama ini dilaksanakan, yang mungkin hanya sekadar rutinitas belaka.

Memang benar bahwa saat ini pembelajaran matematika sudah cukup banyak yang menekankan pada pendekatan yang berorientasi perubahan dan mengenalkan pentingnya pelibatan peserta didik dalam memanfaatkan matematika melalui suatu proses aktif. Dalam proses pembelajaran matematika, sudah cukup banyak guru/dosen yang menciptakan situasi dan kondisi yang memungkinkan peserta didiknya (siswa/ mahasiswa) untuk mengembangkan kemampuan berpikir kritis matematis (Gokhale (1995), Oleinik (2002), Mărcuț (2005), Jacob \& Sam (2007), Aizikovitsh \& Amit (2009).

Beberapa studi mengenai disposisi berpikir kritis, pernah juga dilakukan oleh Leader \& Middleton (2004), Yesildere \& Turnuklu (2006), serta Aizikovitsh \& Amit (2010) yang mengungkap indikator disposisi berpikir kritis di antaranya: (1) pencarian kebenaran, dengan menunjukkan fleksibilitas dalam mempertimbangkan beragam alternatif dan pendapat; (2) keterbukaan pikiran, yang menunjukkan pemahaman dan rasa menghargai pendapat orang lain; (3) analitisitas, dengan menunjukkan kegigihan/ketabahan saat menghadapi kesulitan; (4) sistematisitas, dengan menunjukkan sikap rajin/tekun dalam melakukan pencarian informasi yang relevan, (5) kepercayaan diri, yang mengacu pada rasa percaya diri siswa atas kemampuannya sendiri untuk memberikan alasan/penalaran; (6) rasa ingin tahu, dengan menunjukkan bagaimana siswa yang bersangkutan memiliki perhatian untuk terus peka terhadap informasi (well-informed); (7) kedewasaan, dengan menunjukkan kehati-hatian dalam membuat atau mengubah keputusan.

Terlepas dari masalah itu, semua kajian mengenai kemampuan berpikir dan disposisi kritis yang sudah dilakukan di jenjang sekolah menengah dan perguruan tinggi, belum menunjukkan bagaimana keberhasilan kemampuan berpikir kritis, kreatif, dan investigatif pada mahasiswa calon guru sekolah dasar (mahasiswa PGSD). Jika kemampuan berpikir kritis, kreatif, dan investigatif para mahasiswa calon guru SD tidak dikembangkan selama mengenyam pendidikan kesarjanaannya, maka bukan mustahil setelah mereka lulus dan menjadi guru SD, mereka kesulitan pula untuk mengembangkan kemampuan berpikir dan disposisi kritis siswanya. Padahal, mahasiswa Pendidikan Guru Sekolah Dasar (PGSD) adalah mahasiswa yang disiapkan untuk menjadi guru kelas yang profesional di SD, yang seharusnya mampu menumbuhkembangkan kemampuan berpikir dan disposisi kritis siswanya seperti yang diamanahkan oleh kurikulum di Indonesia. 
Keadaan yang ironis terjadi, karena di satu sisi kemampuan berpikir kritis peserta didik sangat penting untuk dimiliki dan dikembangkan, akan tetapi di sisi lain ternyata kemampuan berpikir kritis peserta didik tersebut masih kurang. Hal ini dapat dilihat dari hasil studi pendahuluan yang dilakukan oleh Maulana (2007) selama beberapa semester terhadap mahasiswa program D-2 dan S-1 PGSD yang memiliki background pendidikan terakhir sangat beragam. Mahasiswa tersebut berasal dari SMA, SMK, MA, dan SPG (khusus pada kelas lanjutan dan dualmodes). Adapun program studi yang mereka ambil adalah IPA, Bahasa, IPS, Manajemen, dan Teknik. Jika mahasiswa tersebut dikelompokkan menjadi kelompok besar, maka terdapat dua kelompok besar yakni mahasiswa yang berlatar belakang IPA dan NON-IPA. Dalam studi pendahuluan yang telah dilakukan, diberikan tes kemampuan berpikir kritis dengan hasilnya bernilai ratarata kurang dari $50 \%$ dari skor maksimal untuk kedua kelompok tersebut (Maulana, 2007; Maulana, 2011).

Semua informasi yang ditemukan di lapangan tersebut-mengenai rendahnya kemampuan berpikir kritis matematis mahasiswa calon guru, khususnya PGSDtidak selayaknya dibiarkan begitu saja. Akan tetapi, perlu kiranya dilakukan sebuah upaya untuk menindaklanjutinya dalam rangka perbaikan, salah satu alternatifnya adalah dengan menerapkan suatu strategi dan pendekatan pembelajaran yang lebih inovatif. Dalam hal ini Ausubel (Ruseffendi, 1992) menyarankan agar sebaiknya digunakan pendekatan yang menggunakan metode pemecahan masalah, inkuiri, dan metode belajar yang menumbuhkembangkan kemampuan berpikir kritis.

Seiring dengan kemampuan berpikir kritis yang harus dikembangkan, maka tak lepas dari ketiga kemampuan tersebut ada disposisi matematis yang harus turut ditumbuhkembangkan secara bersamaan pula. Dalam pembelajaran matematika, pembinaan komponen ranah afektif semacam disposisi matematis (mathematical disposition) akan membentuk keinginan, kesadaran, dedikasi dan kecenderungan yang kuat pada diri peserta didik untuk berpikir dan berbuat secara matematis dengan cara yang positif dan didasari dengan iman, taqwa, dan ahlak mulia (Sumarmo, 2011). Pengertian disposisi matematis seperti di atas pada dasarnya sejalan dengan makna yang terkandung dalam pendidikan budaya dan karakter bangsa. Dengan demikian pengembangan budaya dan karakter, kemampuan berpikir dan disposisi matematis pada dasarnya dapat ditumbuhkan pada diri peserta didik secara bersama-sama. Disposisi matematis yang berkaitan dengan kemampuan berpikir kritis, dalam hal ini diistilahkan sebagai disposisi kritis.

Ketika seseorang sedang melakukan aktivtas berpikir kritis, maka "aku" atau pribadi orang itu memegang peranan 
Maulana, Interaksi PBL-MURDER, Minat Penjurusan, dan Kemampuan Dasar Matematis...

penting. Si "aku" bukanlah faktor yang pasif, melainkan faktor yang mengemudikan perbuatan standar (Kulpe dalam Permana, 2010). Apalagi pribadi tersebut masih berusia remaja yang masih cenderung labil dalam tingkat emosinya. Pada usia remaja seperti ini, kondisi pembelajaran yang tidak kondusif serta kurangnya penguasaan kemampuan dasar bermatematika akan mempengaruhi disposisi peserta didik dalam belajar matematika.

Hasil penelitian Sumarmo, dkk. (dalam Hulukati, 2005) memberikan gambaran bahwa pembelajaran matematika dewasa ini antara lain memiliki karakteristik sebagai berikut: pembelajaran lebih berpusat pada guru, pendekatan yang digunakan lebih bersifat ekspositoris, guru lebih mendominasi proses aktivitas kelas, latihan-latihan yang diberikan lebih banyak yang sifatnya rutin. Sementara itu kurikulum menuntut suatu suatu proses pembelajaran yang student-centered, mengembangkan kreativitas siswa, menciptakan kondisi yang menyenangkan tetapi menantang, mengembangkan kemampuan yang bermuatan nilai, menyediakan pengalaman belajar yang beragam serta belajar melalui perbuatan (learning by doing). Oleh karena itu, perlu ada upaya yang ekstra keras dari semua pihak yang terkait dengan proses pendidikan untuk secara bersama-sama berusaha memperbaiki proses pembelajaran yang terjadi saat ini.
Menyadari pentingnya suatu strategi dan pendekatan pembelajaran untuk mengembangkan kemampuan berpikir mahasiswa, maka mutlak diperlukan adanya pembelajaran matematika yang lebih banyak melibatkan mahasiswa secara aktif dalam proses pembelajaran itu sendiri. Hal ini dapat terwujud melalui suatu bentuk pembelajaran alternatif yang dirancang sedemikian rupa sehingga mencerminkan keterlibatan mahasiswa secara aktif dan konstruktif. Mahasiswa sebagai peserta didik perlu dibiasakan untuk mampu mengkonstruksi sendiri pengetahuannya dan mampu mentransformasikan pengetahuannya tersebut ke dalam situasi lain yang lebih kompleks sehingga pengetahuan tersebut akan menjadi milik peserta didik itu sendiri, yang melekat selamanya. Proses mengkonstruksi pengetahuan dapat dilakukan oleh peserta didik sendiri berdasarkan pengalaman yang telah dimiliki sebelumnya, atau dapat pula berupa hasil penemuan yang melibatkan faktor lingkungan.

Berdasarkan pandangan konstruktivisme, suatu strategi pembelajaran haruslah memiliki ciri-ciri antara lain sebagai berikut: penggunaan waktu yang lebih banyak untuk mengembangkan pemahaman yang dapat meningkatkan kemampuan peserta didik untuk mengalihgunakan pengetahuan, melibatkan peserta didik dalam proses belajar sehingga konsep yang abstrak disajikan lebih konkret, penerapan diskusi dalam kelompok kecil, 
serta penyajian masalah-masalah yang bersifat tidak rutin.

Salah satu pendekatan pembelajaran matematika yang didasari oleh pandangan konstruktivisme adalah pembelajaran berbasis masalah (PBM) atau sering pula disebut dengan istilah problem-based learning (PBL). Dalam prosesnya, pembelajaran seperti ini menyuguhkan suatu lingkungan pembelajaran dengan masalah sebagai basisnya. Masalah dimunculkan sedemikian rupa sehingga peserta didik perlu menginterpretasi suatu masalah, mengumpulkan informasi yang dibutuhkan, menilai alternatif solusi, memilih dan mempresentasikan solusi yang telah dipilihnya. Ketika peserta didik mencoba mengembangkan suatu prosedur dalam menyelesaikan permasalahan, maka sebenarnya mereka sedang mengintegrasikan pengetahuan konseptual dengan keterampilan yang dimilikinya. Oleh karena itu, dalam hal ini secara keseluruhan para peserta didiklah yang membangun pengetahuannya, dengan ditopang oleh keberadaan pengajar yang berperan besar sebagai fasilitator pembelajaran.

Pembelajaran berbasis masalah menyediakan suatu lingkungan belajar yang memberikan banyak kesempatan kepada peserta didik untuk mengembangkan kemampuan berpikir matematisnya. Dengan pembelajaran berbasis masalah, mereka mencoba menggali, mengadaptasi, mengubah prosedur penyelesaian, juga memverifikasi solusi yang sesuai dengan situasi masalah baru yang diperoleh.

Pembelajaran berbasis masalah juga sangat kental dengan nuansa metakognitif, yang menitikberatkan pada aktivitas belajar, membantu dan membimbing peserta didik jika menemui kesulitan (learning obstacles), dan membantu mengembangkan kesadaran metakognisinya, baik dalam hal memilih, mengingat, mengenali kembali, mengorganisasi informasi yang dihadapinya, sampai kepada bagaimana menyelesaikan masalah (Suzana, 2003). Pembelajaran berbasis masalah yang berdasarkan pandangan konstruktivisme ini dapat memicu tumbuh kembangnya keterampilan metakognitif peserta didik, karena proses belajar diawali dengan konflik kognitif dan diatasi oleh peserta didik itu sendiri melalui pengaturan diri (self-regulation), yang akhirnya dalam proses belajar itu peserta didik membangun sendiri pengetahuannya melalui pengalaman dari hasil interaksi dengan lingkungannya.

Salah satu strategi yang digunakan dalam menerapkan pembelajaran berbasis masalah adalah dengan strategi "MURDER". Strategi "MURDER" ini memberikan penekanan bahwa interaksi dan kolaborasi dengan orang lain adalah bagian penting dalam belajar (Santyasa, 2008). Istilah "MURDER" ini merupakan 
akronim dari kata Mood - Understand Recall - Detect - Elaborate - Review. Dalam fase Mood, pembelajaran lebih diarahkan untuk mengatur suasana hati (mood) yang tepat dengan cara relaksasi dan berfokus pada tugas belajar. Fase kedua, Understand, peserta didik diajak untuk memahami bagian materi tertentu dari naskah tanpa menghafalkan. Pada fase Recall, salah satu anggota kelompok memberikan sajian lisan dengan mengulang materi yang dibaca. Lalu fase Detect, anggota mencermati dan mengkritisi munculnya kesalahan, kealpaan catatan, atau perbedaan pandangan. Fase kelima, sesama pasangan meng-Elaborate langkahlangkah 2, 3, 4, dan 5, diulang untuk bagian materi selanjutnya. Terakhir, pada fase Review, peserta didik mengulas kembali hasil pekerjaannya dan mentransmisikan pada pasangan lain dalam kelompoknya. Melalui pembelajaran berbasis masalah berstrategi "MURDER" ini, diharapkan peserta didik (mahasiswa PGSD) dapat mengembangkan kemampuan berpikir dan disposisi matematisnya.

Berdasarkan uraian yang telah dikemukakan di atas, maka perlulah kiranya dilakukan suatu penelitian mengenai alternatif pembelajaran matematika yang diduga dapat mengembangkan kemampuan berpikir dan disposisi kritis matematis. Dalam hal ini, dilakukanlah penelitian yang mengimplementasikan problem-based learning berstrategi "MURDER" untuk meningkatkan kemampuan berpikir dan disposisi kritis matematis mahasiswa PGSD yang diperkirakan sesuai dengan kebutuhan mahasiswa dalam mengembangkan kemampuan berpikir dan disposisi kritis dari yang berlatar belakang berbeda (dalam hal ini tingkat kemampuan dasar, maupun asal sekolah/minat penjurusannya).

\section{METODE}

\section{Desain dan Prosedur Penelitian}

Penelitian ini dilakukan melalui dua tahap, yaitu: 1) tahap persiapan, dan 2) tahap pelaksanaan. Pada tahap persiapan dilakukan penelitian pengembangan (developmental research) bahan ajar pembelajaran berbasis masalah berstrategi "MURDER" dengan menggunakan penelitian desain didaktis (Didactical Design Research-DDR). Sebagaimana dikatakan oleh Suryadi (2010), DDR merupakan sebuah metodologi penelitian yang dikembangkan dari tacit didactical dan pedagogical knowledge.

Suryadi (2010) menjelaskan bahwa DDR ini memliki tiga tahapan, yaitu:

1. Analisis situasi didaktis (ASD) dilakukan oleh dosen dalam pengembangan bahan ajar sebelum diujicobakan dalam peristiwa pembelajaran. ASD berupa sintesis hasil pemikiran dosen tentang berbagai kemungkinan respons mahasiswa yang diprediksi akan muncul pada peristiwa 
pembelajaran dan langkah-langkah antisipasinya.

2. Analisis metapedadidaktik (AM) dilakukan dosen sebelum, pada saat, dan setelah uji coba bahan ajar. AM berupa kemampuan dosen untuk dapat memandang peristiwa pembelajaran secara komprehensif, mengidentifikasi dan menganalisis halhal penting yang terjadi, serta melakukan tindakan cepat dan tepat (scaffolding) untuk mengatasi hambatan pembelajaran (learning obstacles) sehingga tahapan pembelajaran dapat berjalan lancar dan hasil belajar mahasiswa menjadi optimal.

3. Analisis retrosfektif (AR), dilakukan dosen setelah uji coba bahan ajar. Dari AR dilakukan revisi terhadap bahan ajar yang telah dikembangkan sebelumnya sehingga akan dihasilkan suatu bahan ajar yang ideal, yaitu bahan ajar yang sesuai kebutuhan mahasiswa, dapat memprediksi dan mengantisipasi setiap hambatan pembelajaran yang muncul, sehingga tahapan pembelajaran dapat berjalan lancar dan hasil belajar mahasiswa menjadi optimal.

Akhir dari tahap persiapan ini adalah dengan diperolehnya: (1) bahan ajar untuk pembelajaran berbasis masalah berstrategi "MURDER" dengan DDR, pembelajaran berbasis masalah berstrategi "MURDER" tanpa DDR, dan pembelajaran konvensional; seperangkat tes kemampuan dasar matematis (TKDM), tes kemampuan berpikir kritis (TKBK) yang telah memenuhi persyaratan: validitas, reliabilitas, tingkat kesukaran, dan daya pembeda; dan (3) skala disposisi berpikir kritis (SDBK).

Jika tahap persiapan telah selesai, maka dilanjutkan dengan tahap pelaksanaan penelitian yang menggunakan metode kuasi eksperimen dengan desain kelompok kontrol non-ekuivalen (the nonequivalent control group design). Penggunaan metode kuasi eksperimen ini karena tidak dimungkinkan untuk melakukan pengontrolan secara penuh terhadap sampel penelitian, sehingga subjek tidak dikelompokkan secara acak, dan keadaan subjek diterima apa adanya (Ruseffendi, 2003).

Berdasarkan hasil TKDM, mahasiswa pada setiap kelas dikelompokkan menjadi tiga kategori, yaitu: tinggi, sedang, dan rendah. Pengelompokan kemampuan awal matematis mahasiswa ini ditentukan berdasarkan pengkategorian dengan kriteria pengelompokan berdasarkan ratarata skor gabungan seluruh mahasiswa dan simpangan bakunya. Dengan demikian, penelitian kuasi eksperimen dengan the non-equivalent control group design secara ringkas digambarkan sebagai berikut (Fraenkel \& Wallen, 1993; Ruseffendi, 2003).

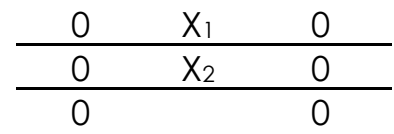

Keterangan: 
$\mathrm{X}_{1}$ : Pembelajaran berbasis masalah berstrategi "MURDER" dengan bahan ajar hasil didactical design research.

$\mathrm{X}_{1}$ : Pembelajaran berbasis masalah berstrategi "MURDER".

0 : Pemberian tes dan non-tes di awal dan akhir pembelajaran.

\section{Populasi dan Sampel}

Populasi penelitian ini adalah mahasiswa Program Studi Pendidikan Guru Sekolah Dasar (PGSD) pada Perguruan Tinggi Negeri yang mengontrak matakuliah Pendidikan Matematika II, yang berada di lingkup Provinsi Jawa Barat dan Banten. Dari populasi tersebut, kemudian diambil sejumlah sampel dalam penelitian ini, sebanyak 119 orang, yang terdistribusikan menjadi 3 kelas. Dari ketiga kelas tersebut dipilih 2 kelas sebagai kelas eksperimen dan 1 kelas lainnya sebagai kelas kontrol. Pada kelas eksperimen, diselenggarakan kegiatan perkuliahan dengan pendekatan pembelajaran berbasis masalah (PBL) berstrategi "MURDER", sedangkan mahasiswa di kelas kontrol memperoleh kegiatan pembelajaran konvensional.

\section{Variabel dan Definisi Operasional}

1. Variabel bebas dinotasikan dengan $X$. Variabel bebas dalam penelitian ini adalah pembelajaran berbasis masalah berstrategi "MURDER" dengan bahan ajar sesuai hasil DDR $\left(X_{1}\right)$, dan pembelajaran berbasis masalah berstrategi "MURDER" biasa $\left(\mathrm{X}_{2}\right)$.

2. Variabel kontrol dalam penelitian berupa minat penjurusan/latar belakang pendidikan (IPA dan Non-
(PA), serta tingkat kemampuan awal matematis mahasiswa, yang terdiri dari tiga kategori, yakni: tinggi, sedang, dan rendah.

3. Variabel terikat dinotasikan dengan $Y$. Variabel terikat dalam penelitian ini berupa kemampuan berpikir kritis dan disposisi kritis matematis.

4. Problem-based learning (PBL) adalah pembelajaran yang dimulai dengan persiapan menuju orientasi masalah nyata atau masalah yang disimulasikan untuk memperoleh pemahaman konsep, relasi antarkonsep, aplikasi konsep, pengkomunikasian konsep, serta untuk mencari, menentukan, mengevaluasi dan mempresentasikan solusi dari masalah menurut penemuan sendiri. Secara umum, pembelajaran berbasis masalah terdiri dari lima macam kegiatan, yakni: (1) orientasi atau persiapan, (2) organisasi, (3) eksplorasi, (4) negosiasi, dan (5) integrasi (dikembangkan dari Karlimah, 2010).

5. Strategi "MURDER" merupakan akronim dari Mood, Understand, Recall, Detect, Elaborate, dan Review (diadopsi dari Santyasa, 2008).

6. Kemampuan berpikir kritis matematis dalam penelitian ini adalah kemampuan berpikir matematis tingkat tinggi yang meliputi aspek kemampuan: (a) mengeksplorasi, (b) mengidentifikasi relevansi, (c) mengklarifikasi, dan (d) merekonstruksi argumen (dikembangkan dari Maulana, 2007). 
7. Disposisi berpikir kritis adalah kecenderungan untuk berpikir dan bersikap dengan cara yang kritis terhadap matematika. Indikator disposisi berpikir kritis ini meliputi: (a) Bertanya secara jelas dan beralasan. (b) Berusaha untuk memahami dengan baik. (c) Menggunakan sumber yang terpercaya. (d) Bersikap atau berpandangan bahwa sesuatu adalah bagian dari keseluruhan yang kompleks. (e) Kembali/relevan ke masalah pokok. (f) Mencoba berbagai strategi. (g) Bersifat terbuka, fleksibel dalam berpikir dan merespons, toleran terhadap perbedaan pendapat. (h) Berani mengambil posisi. (i) Bertindak cepat. (j) Bersikap sensitif terhadap perasaan orang lain. (k) Memanfaatkan cara berpikir orang lain yang kritis (diadopsi dari Sumarmo, 2011).

Keseluruhan data yang terjaring dari perangkat tes kemampuan dasar matematis, tes kemampuan berpikir kritis matematis, dan skala disposisi kritis matematis mahasiswa tersebut kemudian diolah secara kuantitatif, atau dikuantitatifkan dengan harapan dapat menjawab permasalahan penelitian berkaitan dengan interaksi variabelvariabel bebas, kontrol, dan terikat dalam penelitian ini. Adapun analisis data dilakukan secara bertahap, dari mulai uji asumsi normalitas dan homogenitas, OneWay Anova, Two-Way Anova, serta beberapa uji post-hoc.
HASIL DAN PEMBAHASAN

\section{Analisis Kemampuan Dasar Matematis}

Berdasarkan hasil uji statistik One-Way Anova terhadap data TKDM, diperoleh informasi bahwa pada taraf signifikansi $5 \%$, tidak ada perbedaan kemampuan dasar matematis mahasiswa kelas eksperimen 1, eksperimen 2, dan kelas kontrol, sehingga sebelum perlakuan berupa PBL-MURDER dilakukan, keadaan kemampuan dasar matematis ketiga kelompok tersebut secara signifikan adalah sama. Dari hasil tes ini juga, seluruh kelompok sampel dibagi menjadi tiga kelompok, yaitu kategori KDM tinggi/unggul $(x>\bar{x}+s)$, sedang/papak $(\bar{x}-s<x \leq \bar{x}+s)$, dan rendah/asor $(x \leq \bar{x}-s)$. Pada kelas eksperimen 1, dari 40 mahasiswa diketahui 9 unggul, 22 papak, dan 9 asor. Pada kelas eksperimen 2, dari 40 mahasiswa terdapat 9 unggul, 22 papak, dan 9 asor. Kemudian pada kelas kontrol, ada 7 unggul, 23 papak, dan 9 asor.

\section{Pencapaian Kemampuan Berpikir Kritis Matematis}

Statistika deskriptif memberikan penjelasan bahwa pada kelas eksperimen 1, rata-rata pencapaian akhir kemampuan berpikir kritis matematis mahasiswa PGSD adalah 68,75 dengan simpangan baku 11,62. Sementara pada kelas eksperimen 2, diperoleh rata-rata pencapaian akhir kemampuan berpikir kritis matematis sebesar 61,81 dengan simpangan baku 11,56. Kemudian pada kelas kontrol diketahui rata-rata pencapaian akhir 
Maulana, Interaksi PBL-MURDER, Minat Penjurusan, dan Kemampuan Dasar Matematis...

kemampuan berpikir kritis matematisnya 53,08 dengan simpangan baku 9,48.

Pada taraf signifikansi 5\%, dengan menggunakan uji Levene, diketahui bahwa data pencapaian kemampuan berpikir kritis matematis mahasiswa pada ketiga kelompok adalah homogen ( $p$ value $=0,342$ ). Langkah berikutnya adalah menentukan apakah terdapat perbedaan rata-rata pancapaian kemampuan berpikir kritis matematis dengan One-Way Anova. Pada taraf signifikansi $5 \%$ diketahui bahwa terdapat perbedaan yang signifikan antara ketiga kelompok ( $p$-value
$=0,000)$. Uji lanjutan Scheffe memberikan informasi bahwa ternyata rata-rata pencapaian kemampuan berpikir kritis matematis ketiga kelompok tersebut seluruhnya berbeda (semua p-value kurang dari 0,05). Artinya, perlakuan berupa PBL-MURDER dengan menggunakan bahan ajar hasil kajian DDR lebih baik daripada pembelajaran PBLMURDER biasa dan konvensional, serta pembelajaran PBL-MURDER biasa pun lebih baik daripada pembelajaran konvensional dalam pencapaian kemampuan berpikir kritis matematis mahasiswa PGSD.

Tabel 1. Uji Lanjutan Scheffe terhadap Kemampuan Berpikir Kritis

\begin{tabular}{|l|l|r|r|r|}
\hline \multicolumn{1}{|c|}{$(\mathbf{I})$ Kelas } & \multicolumn{1}{|c|}{$(\mathrm{J})$ Kelas } & Mean Difference (I-J) & \multicolumn{1}{c|}{ Std. Error } & \multicolumn{1}{c|}{ Sig. } \\
\hline \multirow{2}{*}{ Eksperimen_1 } & Eksperimen_2 & $6.93750^{*}$ & 2.44712 & .021 \\
\cline { 2 - 5 } & Kontrol & $15.67308^{*}$ & 2.46276 & .000 \\
\hline \multirow{2}{*}{ Eksperimen_2 } & Eksperimen_1 & $-6.93750^{*}$ & 2.44712 & .021 \\
\cline { 2 - 5 } & Kontrol & $8.73558^{*}$ & 2.46276 & .003 \\
\hline Kontrol & Eksperimen_1 & $-15.67308^{*}$ & 2.46276 & .000 \\
\cline { 2 - 5 } & Eksperimen_2 & $-8.73558^{*}$ & 2.46276 & .003 \\
\hline
\end{tabular}

*. The mean difference is significant at the 0.05 level.

\section{Pencapaian Disposisi Berpikir Kritis Matematis}

Statistika deskriptif memberikan penjelasan bahwa pada kelas eksperimen 1, rata-rata pencapaian akhir disposisi berpikir kritis matematis mahasiswa PGSD adalah 87,38 dengan simpangan baku 7,38. Sementara pada kelas eksperimen 2, diperoleh ratarata pencapaian akhir disposisi berpikir kritis matematis sebesar 82,92 dengan simpangan baku 7,68. Kemudian pada kelas kontrol diketahui rata-rata pencapaian akhir disposisi berpikir kritis matematisnya 84,49 dengan simpangan baku 6,02.

Pada taraf signifikansi 5\%, dengan menggunakan uji Levene, diketahui bahwa data pencapaian disposisi berpikir kritis matematis mahasiswa pada ketiga kelompok adalah homogen ( $p$-value = 0,486). Langkah berikutnya adalah menentukan apakah terdapat perbedaan rata-rata pancapaian disposisi berpikir kritis matematis dengan One-Way Anova. Pada taraf signifikansi 5\% diketahui bahwa terdapat perbedaan yang signifikan 
antara ketiga kelompok ( $p$-value $=0,019)$. Uji lanjutan Scheffe memberikan informasi bahwa ternyata rata-rata pencapaian disposisi berpikir kritis matematis pada kelas eksperimen 1 berbeda dengan kelas eksperimen 2, sementara kelas kontrol memiliki kesamaan dengan kelas eksperimen 1 maupun kelas eksperimen 2. Temuan ini memberikan informasi berharga bahwa kegiatan pembelajaran yang menggunakan pendekatan/strategi sama, akan terjadi perbedaan jika ditinjau dari penggunaan bahan ajarnya. Dalam hal ini, pembelajaran yang menggunakan bahan ajar hasil kajian penelitian desain didaktis (DDR) memberikan pengaruh yang lebih baik daripada pembelajaran yang tidak menggunakan bahan ajar hasil kajian DDR.

Tabel 2. Uji Lanjutan Scheffe terhadap Kemampuan Berpikir Kritis

\begin{tabular}{|l|l|r|r|r|}
\hline \multicolumn{1}{|c|}{$(\mathbf{I})$ Kelas } & \multicolumn{1}{|c|}{$(\mathbf{J})$ Kelas } & Mean Difference (I-J) & \multicolumn{1}{c|}{ Std. Error } & \multicolumn{1}{c|}{ Sig. } \\
\hline \multirow{2}{*}{ Eksperimen_1 } & Eksperimen_2 & $4.45000^{*}$ & 1.58140 & .022 \\
\cline { 2 - 5 } & Kontrol & 2.88782 & 1.59150 & .197 \\
\hline \multirow{2}{*}{ Eksperimen_2 } & Eksperimen_1 & $-4.45000^{*}$ & 1.58140 & .022 \\
\cline { 2 - 5 } & Kontrol & -1.56218 & 1.59150 & .619 \\
\hline \multirow{2}{*}{ Kontrol } & Eksperimen_1 & -2.88782 & 1.59150 & .197 \\
\cline { 2 - 5 } & Eksperimen_2 & 1.56218 & 1.59150 & .619 \\
\hline
\end{tabular}

*. The mean difference is significant at the 0.05 level.

Interaksi antara PBL-MURDER, Minat

Penjurusan, dan Kemampuan Dasar

\section{Matematis}

Dengan menggunakan Two-Way Anova pada taraf signifikansi 5\%, diperoleh beberapa temuan menarik sehubungan dengan interaksi antara pendekatan berbasis masalah (PBL) berstrategi "MURDER", minat penjurusan, serta kemampuan dasar matematis yang dimiliki mahasiswa PGSD. Ringkasan mengenai hasil uji Two-Way Anova tersebut disajikan dalam tabel berikut ini.

Tabel 3. Interaksi antara PBL-MURDER, Minat Penjurusan, dan Kemampuan Dasar Matematis, terhadap Pencapaian Akhir Kemampuan Berpikir dan Disposisi Kritis Mahasiswa PGSD

\begin{tabular}{|l|l|c|r|r|r|r|}
\hline \multicolumn{2}{|c|}{ Tests of Between-Subjects Effects } \\
\hline \multirow{3}{*}{ Source } & $\begin{array}{l}\text { Dependent } \\
\text { Variable }\end{array}$ & $\begin{array}{c}\text { Type III Sum of } \\
\text { Squares }\end{array}$ & df & Mean Square & \multicolumn{1}{c|}{$\boldsymbol{F}$} & \multicolumn{1}{c|}{ Sig. } \\
\hline \multirow{2}{*}{ Corrected Model } & KB_Kritis & 9816.021 & 17 & 577.413 & 6.520 & .000 \\
\cline { 2 - 7 } & D_Kritis & $1836.762^{\mathrm{b}}$ & 17 & 108.045 & 2.496 & .003 \\
\hline \multirow{2}{*}{ Intercept } & KB_Kritis & 332280.072 & 1 & 332280.072 & $3.752 \mathrm{E} 3$ & .000 \\
\cline { 2 - 7 } & D_Kritis & 625491.344 & 1 & 625491.344 & $1.445 \mathrm{E}$ & .000 \\
\hline Kelompok_KDM & KB_Kritis & 1582.959 & 2 & 791.480 & 8.937 & .000 \\
\cline { 2 - 7 } & D_Kritis & 259.119 & 2 & 129.559 & 2.993 & .055 \\
\hline
\end{tabular}


Maulana, Interaksi PBL-MURDER, Minat Penjurusan, dan Kemampuan Dasar Matematis...

\begin{tabular}{|c|c|c|c|c|c|c|}
\hline \multirow[t]{2}{*}{ Minat_Jurusan } & KB_Kritis & 984.217 & 1 & 984.217 & 11.113 & .001 \\
\hline & D_Kritis & 479.718 & 1 & 479.718 & 11.080 & .001 \\
\hline \multirow[t]{2}{*}{ Kelas } & KB_Kritis & 3681.698 & 2 & 1840.849 & 20.786 & .000 \\
\hline & D_Kritis & 204.824 & 2 & 102.412 & 2.365 & .099 \\
\hline \multirow{2}{*}{$\begin{array}{l}\text { Kelompok_KDM* } \\
\text { Minat_Jurusan }\end{array}$} & KB_Kritis & 47.895 & 2 & 23.947 & .270 & .764 \\
\hline & D_Kritis & 101.811 & 2 & 50.905 & 1.176 & .313 \\
\hline \multirow{2}{*}{$\begin{array}{l}\text { Kelompok_KDM* } \\
\text { Kelas }\end{array}$} & KB_Kritis & 371.455 & 4 & 92.864 & 1.049 & .386 \\
\hline & D_Kritis & 242.999 & 4 & 60.750 & 1.403 & .238 \\
\hline \multirow{2}{*}{$\begin{array}{l}\text { Minat_Jurusan * } \\
\text { Kelas }\end{array}$} & KB_Kritis & 608.363 & 2 & 304.182 & 3.435 & .036 \\
\hline & D_Kritis & 116.032 & 2 & 58.016 & 1.340 & .266 \\
\hline \multirow{2}{*}{$\begin{array}{l}\text { Kelompok_KDM * } \\
\text { Minat_Jurusan * } \\
\text { Kelas }\end{array}$} & KB_Kritis & 295.406 & 4 & 73.852 & .834 & .507 \\
\hline & D_Kritis & 199.331 & 4 & 49.833 & 1.151 & .337 \\
\hline \multirow[t]{2}{*}{ Error } & KB_Kritis & 8944.798 & 101 & 88.562 & & \\
\hline & D_Kritis & 4372.700 & 101 & 43.294 & & \\
\hline \multirow[t]{2}{*}{ Total } & KB_Kritis & 465656.250 & 119 & & & \\
\hline & D_Kritis & 864625.000 & 119 & & & \\
\hline \multirow[t]{2}{*}{ Corrected Total } & KB_Kritis & 18760.819 & 118 & & & \\
\hline & D_Kritis & 6209.462 & 118 & & & \\
\hline \multicolumn{3}{|c|}{ a. R Squared $=.523$ (Adjusted R Squared $=.443$ ) } & & & & \\
\hline \multicolumn{3}{|c|}{ b. R Squared $=.296$ (Adjusted R Squared $=.177$ ) } & & & & \\
\hline
\end{tabular}

Tabel 3 di atas mengindikasikan beberapa hasil temuan sebagai berikut ini.

1. Kemampuan dasar matematis sangat berpengaruh terhadap pencapaian akhir kemampuan berpikir kritis matematis mahasiswa PGSD ( $p$-valve = $0,000)$. Akan tetapi kemampuan dasar matematis tersebut tidak berpengaruh terhadap pencapaian akhir disposisi kritisnya $(p$-value $=0,055)$.

2. Minat penjurusan memiliki pengaruh yang signifikan terhadap terhadap pencapaian akhir, baik kemampuan berpikir kritis matematis maupun disposisi kritis mahasiswa PGSD ( masing-masing $p$-value $=0,001$ ).

3. Pendekatan pembelajaran memiliki pengaruh yang signifikan terhadap pencapaian kemampuan berpikir kritis matematis mahasiswa PGSD ( $p$-value = 0,000). Akan tetapi adanya perbedaan pendekatan tersebut tidak berpengaruh terhadap pencapaian akhir disposisi kritisnya ( $p$-value = 0,099).

4. Interaksi antara kemampuan dasar dan minat penjurusan tidak memiliki pengaruh gabungan terhadap besarnya perbedaan dalam pencapaian kemampuan berpikir dan disposisi kritis mahasiswa PGSD ( $p$-value masing-masing sebesar 0,764 dan $0,313)$.

5. Interaksi antara kemampuan dasar dan jenis pendekatan pembelajaran yang dipilih, ternyata tidak memiliki pengaruh gabungan terhadap besarnya perbedaan dalam pencapaian kemampuan berpikir dan 
disposisi kritis mahasiswa PGSD (p-value masing-masing sebesar 0,386 dan $0,238)$.

6. Interaksi antara minat penjurusan dan pendekatan pembelajaran memiliki pengaruh yang signifikan terhadap pencapaian kemampuan berpikir kritis matematis $(p$-value $=0,036)$, namun tidak memiliki pengaruh terhadap besarnya perbedaan dalam pencapaian disposisi kritis mahasiswa PGSD ( $p$-value $=0,266)$.

7. Secara keseluruhan, interaksi antara pendekatan pembelajaran berbasis masalah, kemampuan dasar matematis, dan minat penjurusan mahasiswa, ternyata tidak memiliki pengaruh gabungan terhadap besarnya perbedaan dalam pencapaian kemampuan berpikir dan disposisi kritis mahasiswa PGSD ( $p$-value masing-masing sebesar 0,507 dan $0,337)$.

Melalui serangkaian uji hipotesis, diketahui bahwa raw input mahasiswa PGSD yang menjadi subjek penelitian memiliki kemampuan awal atau kemampuan dasar matematis yang relatif sama. Dengan kata lain, dapat dipahami bahwa seluruh mahasiswa baru yang lulus dalam seleksi masuk PGSD di lokasi penelitian memang melalui tahapan yang sama sehingga kemampuan generik, khususnya kemampuan dasar matematisnya tidak berbeda. Begitu pula setelah dilakukan persebaran subkelompok unggul, papak, dan asor, di ketiga kelas penelitian proporsi ketiga subkelompok tersebut relatif merata.

Kemampuan berpikir kritis matematis mahasiswa PGSD di akhir pembelajaran ternyata memiliki perbedaan, ditinjau dari sudut pandang kegiatan pembelajaran yang digunakan. Dari hasil analisis data dan uji hipotesis statistik, diperoleh informasi berharga bahwa pembelajaran PBL-MURDER dengan menggunakan bahan ajar hasil kajian DDR lebih baik daripada pembelajaran PBL-MURDER biasa dan konvensional, serta pembelajaran PBL-MURDER biasa pun lebih baik daripada pembelajaran konvensional dalam pencapaian kemampuan berpikir kritis matematis mahasiswa PGSD. Dari sini dapat diketahui dengan jelas bahwa hasil belajar peserta didik akan lebih optimal jika bahan ajar didesain sedemikian rupa sehingga hambatan belajar peserta didik tersebut dapat diminimalisasi (Suryadi, 2010). Temuan pada aspek kognitif (kemampuan berpikir kritis) tersebut nyatanya diperkuat pula dengan temuan lain pada aspek afektif (disposisi kritis). Temuan ini memberikan informasi penting bahwa pembelajaran yang menggunakan bahan ajar hasil kajian penelitian desain didaktis (DDR) memberikan pengaruh yang lebih baik daripada pembelajaran yang tidak menggunakan bahan ajar hasil kajian DDR, dengan catatan pendekatan yang digunakan adalah sama. 
Di samping optimalisasi bahan ajar melalui serangkaian kajian DDR, diketahui pula bahwa kemampuan dasar matematis sangat berpengaruh terhadap pencapaian akhir kemampuan berpikir kritis matematis mahasiswa PGSD. Ini mengandung pengertian yang sejalan dengan temuan Suryadi (2005), Maulana (2007), dan Ibrahim (2011), bahwa mahasiswa yang pada awalnya berkemampuan dasar unggul akan memiliki kecenderungan untuk mencapai kemampuan berpikir kritis yang tinggi pula. Di samping kemampuan dasar yang memiliki pengaruh signifikan terhadap pencapaian kemampuan berpikir kritis mahasiswa, ternyata minat penjurusan pun memiliki pengaruh yang signifikan terhadap terhadap pencapaian akhir, baik kemampuan berpikir kritis matematis maupun disposisi kritis mahasiswa. Mahasiswa PGSD yang berasal dari kelompok IPA memiliki kemampuan berpikir dan disposisi kritis yang lebih baik daripada kelompok Non-IPA.

Dari sudut pandang pendekatan dan strategi pembelajaran, diketahui pengaruhnya yang signifikan terhadap pencapaian kemampuan berpikir kritis matematis mahasiswa PGSD. Artinya, pembelajaran PBL-MURDER, memberikan kesempatan kepada mahasiswa PGSD untuk lebih mampu mencapai kemampuan berpikir kritis matematis yang lebih tinggi jika dibandingkan pembelajaran yang bersifat konvensional. Akan tetapi di sisi lain, perbedaan pendekatan tersebut tidak berpengaruh terhadap perbedaan rata-rata pencapaian akhir disposisi kritisnya. Hal ini bisa saja dipahami, sebagaimana teori conditioning dari Pavlov (Ruseffendi, 1992), bahwa untuk menumbuhkembangkan aspek sikap (afektif) dalam diri peserta didik, tidak bisa dilakukan secara instan, tetapi pembiasaan dalam waktu yang cukup lama.

Paparan pembahasan di atas memberikan gambaran, bahwa minat penjurusan dan jenis pembelajaran memberikan dampak yang signifikan terhadap perolehan kemampuan berpikir kritis matematis mahasiswa. Kemudian setelah dilakukan uji interaksi antara keduanya, semakin kuat temuan tersebut karena diketahui bahwa terdapat pengaruh gabungan (interaksi) dari minat penjurusan dan pendekatan pembelajaran terhadap perbedaan ratarata pencapaian akhir kemampuan berpikir kritis matematis mahasiswa PGSD.

\section{SIMPULAN}

Beberapa simpulan dapat ditarik dari hasil pembahasan di atas. Pertama, raw input mahasiswa PGSD memiliki kemampuan awal atau kemampuan dasar matematis yang relatif sama. Kemampuan dasar matematis (unggul, papak, dan asor) sangat berpengaruh terhadap achievement atau pencapaian akhir kemampuan berpikir kritis matematis mahasiswa PGSD. Mahasiswa yang pada awalnya berkemampuan dasar unggul 
akan memiliki kecenderungan untuk mencapai kemampuan berpikir kritis yang tinggi pula. Kedua, pencapaian akhir berupa kemampuan berpikir kritis matematis mahasiswa PGSD yang mengikuti pembelajaran berbasis masalah (problem based learning) berstrategi mood - understand - recall - detect elaborate - review dengan menggunakan bahan ajar hasil kajian didactical design research (PBL-MURDER dan DDR) lebih baik daripada pembelajaran PBL-MURDER biasa dan konvensional, serta pembelajaran PBL-MURDER biasa pun lebih baik daripada pembelajaran konvensional dalam pencapaian kemampuan berpikir kritis matematis mahasiswa PGSD. Dengan demikian, upaya untuk meminimalisasi hambatan belajar (learning obstacles) melalui perancangan bahan ajar yang baik dan lebih sesuai dengan kebutuhan peserta didik, akan dapat mengoptimalkan hasil belajar peserta didik tersebut. Ketiga, dengan pendekatan atau strategi pembelajaran yang sama tetapi berbeda dalam penggunaan bahan ajarnya, akan memberikan dampak berbeda pada pencapaian disposisi kritis peserta didik. Dalam hal ini, PBL-MURDER dengan DDR memberikan pengaruh yang lebih baik daripada PBL-MURDER biasa terhadap disposisi kritis mahasiswa PGSD. Keempat, minat penjurusan memiliki pengaruh yang signifikan terhadap terhadap pencapaian kemampuan berpikir kritis matematis dan disposisi kritis mahasiswa PGSD. Kelima, interaksi antara minat penjurusan dan pendekatan pembelajaran memiliki pengaruh yang signifikan terhadap perbedaan rata-rata kemampuan akhir berpikir kritis matematis, namun tidak memiliki pengaruh terhadap besarnya perbedaan dalam pencapaian disposisi kritis mahasiswa PGSD. Terakhir, interaksi antara pendekatan pembelajaran, kemampuan dasar matematis, dan minat penjurusan mahasiswa, ternyata tidak memiliki pengaruh gabungan terhadap besarnya perbedaan rata-rata pencapaian kemampuan berpikir dan disposisi kritis mahasiswa PGSD.

Di bagian penutup tulisan ini, ada beberapa saran yang bisa dikemukakan. Pertama, kajian mengenai interaksi antara jenis pendekatan/strategi pembelajaran, minat penjurusan, serta kemampuan dasar matematis mahasiswa PGSD tidak hanya dilihat pengaruhnya pada kemampuan berpikir dan disposisi kritis matematis saja, tetapi bisa juga diperluas pada kemampuan berpikir dan disposisi kreatif maupun investigatif. Kedua, pembahasan kali ini hanya dilakukan pada data hasil tes akhir kemampuan berpikir kritis matematis dan skala disposisi akhir saja, tanpa melibatkan hasil perhitungan kemampuan berpikir kritis awal, disposisi kritis awal, serta normalized gain untuk mengukur seberapa tinggi peningkatannya. Untuk itu, agar pembahasan berikutnya lebih lengkap, maka perlu kiranya dilakukan analisis terhadap data kemampuan berpikir dan disposisi awal serta perkembangannya. 


\section{REFERENSI}

Abdi, A. (2004). Senyum guru matematika dan upaya bangkitkan gairah siswa. [Online]. Tersedia: http://www.waspada.co.id/serba_serbi /pendidikan/artikel.php?article_id=6722

Aizikovitsh, E. \& Amit, M. (2009). Promoting critical thinking abilities via probability instruction. In M. Tzekaki, M. Kaldrimidou, \& C. Sakonidis (Eds.). Proceedings of the 33rd Conference of the International Group for the Psychology of Mathematics Education. 2, pp. 17-24. Greece: PME.

Aizikovitsh, E. \& Amit, M. (2010). Evaluating an infusion approach to the teaching of critical thinking skills through mathematics. Procedia Social and Behavioral Sciences. 2, Year 2010, pp. 3818-3822.

Arends, R. I. (2004). Learning to teach. New York: Mc Graww Hill, Co. Inc.

Darhim. (2004). Pengaruh pembelajaran matematika kontekstual terhadap hasil belajar dan sikap siswa sekolah dasar kelas awal dalam matematika. (Disertasi). Program Pascasarjana Universitas Pendidikan Indonesia. Bandung: Tidak dipublikasikan.

Ennis, R. H. (2000). A super-streamlined conception of critical thinking [Online]. Tersedia:

http://www.criticalthinking.net/SSConc CTApr3. html

Fraenkel, J. C. \& Wallen, N. E. (1993), How to design and evaluate research in education. $2^{\text {nd }}$ edition. New York: McGraw-Hill Inc.

Gokhale, A. A. (1995). Collaborative learning enhances critical thinking. Journal of Technology Education (JTE). Fall 1995, 7(1), pp. 1-9.

Hulukati, E. (2005). Mengembangkan kemampuan komunikasi dan pemecahan masalah siswa smp melalui pembelajaran generatif. (Disertasi). Program Pascasarjana Universitas
Pendidikan Indonesia. Bandung: Tidak dipublikasikan.

Ibrahim. (2011). Peningkatan kemampuan komunikasi, penalaran, pemecahan matematis, serta kecerdasan emosional, melalui pembelajaran berbasis masalah pada siswa sekolah menengah atas. (Disertasi). Sekolah Pascasarjana Universitas Pendidikan Indonesia. Bandung: Tidak dipublikasikan.

Jacob, S. M. \& Sam, H. K. (2008). Critical thinking in online mathematics discussion forums and mathematical achievement. Proceedings of the Thirteenth Asian Technology Conference in Mathematics. Suan Sunandha Rajabhat University, Bangkok, Thailand, 15 - 19 December, 2008. ISBN 978-0-9821 164-1-8.

Jennings, S. \& Dunne, R. (1998). Discussion papers. Tersedia: http://www.ex.ac.uk/telematics/T3/mat hs/mathfram.htm

Karlimah (2010). Mengembangkan kemampuan komunikasi dan pemecahan masalah serta disposisi matematis mahasiswa pgsd melalui pembelajaran berbasis masalah. (Disertasi). Sekolah Pascasarjana Universitas Pendidikan Indonesia. Bandung: Tidak dipublikasikan.

Leader, L. F. \& Middleton, J. A. (2004). Promoting critical thinking dispositions by using problem solving in middle school mathematics. RMLE Online (Research in Middle Level EducationOnline). 28(1), Year 2004, pp. 1-13. Tersedia:

http://www.nmsa.org/portals/0/pdf/pu blications/RMLE/rmle_vol28_nol_article3 .pdf

Maier, H. (1985). Kompendium didaktik matematika. Bandung: CV. Remaja Rosdakarya.

Mărcuț, I. (2005). Critical thinking-applied to the methodology of teaching mathematics. Journal Educatia Matematică. 1 (1), pp. 57-66. 
Maulana. (2007). Alternatif pembelajaran matematika dengan pendekatan metakognitif untuk meningkatkan kemampuan berpikir kritis mahasiswa PGSD. (Tesis). Program Pascasarjana Universitas Pendidikan Indonesia. Bandung: Tidak dipublikasikan.

Maulana. (2011). Mathematical creative thinking which is necessary. Proceeding the $2^{\text {nd }}$ International Conference on Basic Education, Indonesia University of Education, 28-29 October 2011.

Oleinik, T. (2002). Development of critical thinking in mathematics course. In P. Valero \& O. Skovsmose (Eds.). Proceeding of the $3^{\text {rd }}$ International Mathematics Education and Society Conference. Copenhagen: Center for Research in Learning Mathematics, pp. 1-3.

Permana, Y. (2010). Mengembangkan kemampuan pemahaman, komunikasi, dan disposisi matematis siswa sekolah menengah atas melalui Model-Eliciting Activities. (Disertasi). Sekolah Pascasarjana Universitas Pendidikan Indonesia. Bandung: Tidak dipublikasikan.

Resnick, L. B. (1987). Education and learning to think. CRMSTE. [Online] Tersedia:

http://www.nap.edu/catalog/1032.html

Rif'at, M. (2001). Pengaruh pola-pola pembelajaran visual dalam rangka meningkatkan kemampuan menyelesaikan masalah-masalah matematika. (Disertasi). Sekolah Pascasarjana Universitas Pendidikan Indonesia. Bandung: Tidak dipublikasikan.

Ruseffendi, E. T. (1992). Pengantar kepada membantu guru mengembangkan kompetensinya dalam pengajaran matematika untuk meningkatkan cbsa. Bandung: Tarsito.

Ruseffendi, E. T. (2003). Dasar-dasar penelitian pendidikan dan bidang eksakta lainnya. Semarang: Unnes Press.
Santyasa, I. W. (2008). Pembelajaran berbasis masalah dan pembelajaran kooperatif. Makalah pada Pelatihan tentang Pembelajaran dan Asesmen Inovatif bagi Guru-guru Sekolah Menengah di Kecamatan Nusa Penida, 22 - 24 Agustus 2008.

Schoenfeld, A. H. (1992). Learning to think mathematically: Problem solving, metacognition, and sense-making in mathematics. In D. A. Grouws (Ed.). Handbook of research on mathematics teaching and learning. pp. 334-370. Reston, VA: National Council of Teachers of Mathematics.

Slettenhaar (2000). Adapting realistic mathematics education in the indonesian context. Majalah IImiah Himpunan Matematika Indonesia (Prosiding Konferensi Nasional Matematika X ITB, 17-20 Juli 2000).

Sumarmo, U. (2011). Pendidikan budaya dan karakter serta pengembangan berfikir dan disposisi matematik: pengertian dan implementasinya dalam pembelajaran. Makalah disajikan dalam seminar pendidikan matematika di Universitas Siliwangi Tasikmalaya, 15 Oktober 2011.

Suryadi, D. (2005). Penggunaan pendekatan pembelajaran tidak langsung serta pendekatan gabungan langsung dan tidak langsung dalam rangka meningkatkan kemampuan berpikir matematik tingkat tinggi siswa SLTP. (Disertasi). Sekolah Pascasarjana Universitas Pendidikan Indonesia. Bandung: Tidak dipublikasikan.

Suryadi, D. (2010). Didactical design research (DDR) dalam pengembangan pembelajaran matematika. Makalah Seminar Nasional Pembelajaran MIPA di UM Malang, 13 November 2010.

Suzana, Y. (2003). Meningkatkan kemampuan pemahaman dan penalaran matematis siswa smu melalui pembelajaran dengan pendekatan metakognitif. (Tesis). Program Pascasarjana Universitas Pendidikan 
Maulana, Interaksi PBL-MURDER, Minat Penjurusan, dan Kemampuan Dasar Matematis...

Indonesia. $\quad$ Bandung: Tidak

dipublikasikan.

Wahab, A. A. (1996). Pendidikan kewarganegaraan. Jakarta: Depdikbud.

Wahyudin (1999). Kemampuan guru matematika, calon guru matematika, dan siswa dalam mata pelajaran matematika. (Disertasi). Sekolah Pascasarjana Universitas Pendidikan Indonesia. Bandung: Tidak dipublikasikan.

Yesildere, S. \& Turnuklu, E. B. (2006). The effect of project-based learning on preservice primary mathematics teachers' critical thinking dispositions. International Journal of Science and Mathematics Education. 6/October 2006), pp. 1-11. 